\title{
C-Telopeptide in Relation with Osteoporosis Risk Classification Using Osteoporosis Self Assessment Tools for Asian (OSTA) in Postmenopausal Women
}

\author{
Hubungan antara C-Telopeptide dengan Klasifikasi Risiko Osteoporosis \\ Menggunakan Osteoporosis Self Assesment Tools for Asian (OSTA) \\ pada Perempuan Pascamenopause
}

\author{
Willy Pangestu, Maria Loho, Freddy Wagey \\ Department of Obstetrics and Gynecology \\ Faculty of Medicine University of Sam Ratulangi/ \\ Prof. Dr. RD Kandou Hospital \\ Manado
}

\begin{abstract}
Objective: To determine the correlation between C-telopeptide with osteoporosis risk by using Osteoporosis Self Assessment Tools for Asian (OSTA) in postmenopausal women.

Method: An analytic cross-sectional study of 31 postmenopausal women in Prof. Dr. RD Kandou Hospital, Manado. Samples were collected through consecutive sampling. Data was analyzed using Pearson test with significance level of $\mathrm{p}>0.05$.

Result: Our sample consisted of 31 postmenopausal women. Mean OSTA score is $-1.02 \mp 2.54$. Sixteen women (51.61\%) were deemed to have low risk, 8 women $(25.81 \%)$ deemed to have moderate risk and 7 women $(22.58 \%)$ deemed high risk based on the OSTA score. The mean C-telopeptide plasma level of our sample is $0.52 \mp 0.25$ $\mu \mathrm{g} / \mathrm{l}$. We found plasma C-telopeptide level and OSTA score were normally distributed. Correlation analysis using Pearson test identified a significant negative correlation between plasma C-telopeptide level and OSTA score ( $r=-0.768 ; \mathrm{p}=0.001)$.

Conclusion: There is a significant negative correlation between plasma C-telopeptide level with risk of osteoporosis based on OSTA score in postmenopausal women.

[Indones J Obstet Gynecol 2015; 1: 32-37]

Keywords: OSTA score, plasma C-telopeptide, postmenopausal women
\end{abstract}

\begin{abstract}
Abstrak
Tujuan: Mengetahui korelasi antara C-Telopeptide dengan risiko osteoporosis dengan menggunakan OSTA pada perempuan pascamenopause.

Metode: Penelitian ini merupakan studi potong lintang analitik yang mengikutsertakan 31 perempuan pascamenopause yang kontrol di poliklinik bagian kebidanan dan kandungan RSUP Prof. Dr. RD Kandou Manado secara consecutive sampling. Analisis data menggunakan uji Pearson dengan tingkat kemaknaan $p<0,05$.

Hasil: Sampel kami terdiri dari 31 perempuan pascamenopause. Rerata nilai OSTA adalah -1,02 2,54. Enam belas perempuan $(51,61 \%)$ didapatkan memiliki risiko rendah, 8 perempuan $(25,81 \%)$ didapatkan memiliki risiko sedang dan 7 perempuan (22,58\%) dengan risiko tinggi menurut klasifikasi berdasarkan nilai OSTA. Rerata kadar $C$ -

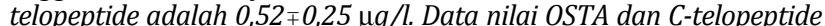
memiliki pola distribusi normal $(p>0,05)$. Hasil analisis korelasi antara nilai OSTA dengan kadar C-telopeptide didapatkan nilai $r=-0,768 \mathrm{de}$ ngan nilai $p=0,001$.
\end{abstract}

Kesimpulan: Terdapat hubungan negatif yang bermakna antara kadar $C$-Telopeptide plasma dengan klasifikasi risiko osteoporosis berdasarkan nilai OSTA pada perempuan pascamenopause.

[Maj Obstet Ginekol Indones 2015; 1: 32-37]

Kata kunci: C-telopeptide plasma, nilai OSTA, perempuan pascamenopause

Correspondence: Willy Pangestu. Address: Malalayang I Tanawangko Manado, telephone: 085340165248. email: willymuliawanpangestu@yahoo.com

\section{INTRODUCTION}

Menopause is defined as a woman who does not menstruate at the age of 51 to 65 years for more than 12 months spontaneously with levels of follicle stimulating hormone (FSH) $>40 \mathrm{mIU} / \mathrm{ml}$ and estradiol levels $<30 \mathrm{pg} / \mathrm{ml}^{1}$

The incidence of osteoporosis is increasing in the elderly population. In women aged over 50 years old, incidence of osteoporosis was found to be $30 \%, 37-54 \%$ were found to have osteopenia and $54 \%$ had a higher risk of osteoporotic fracture. The prevalence of osteoporosis in women with a mean age of 66.36 years is $91.7 \%$. Approximately $35 \%$ of postmenopausal women will suffer from osteoporosis, and 50\% will have osteopenia. ${ }^{1,2}$

Bone is comprised of the bone matrix, containing 90\% collagen (type-1 collagen containing $\mathrm{N}$ telopeptides, C-telopeptide and deoxypyridinolines) and 10\% protein (osteocalcine, osteonectin, 
osteopontin); bone minerals (calcium and phosphate); and bone cells (osteoclasts, osteoblasts and lining cells). ${ }^{3-5}$

Several cross-sectional studies indicate that bone turnover will increase rapidly after a woman enters menopause, where there is an increase in levels of osteocalcin and bone alkaline phosphatase by as much as $50 \%$, and increased levels of Ctelopeptide by $50-150 \%$. C-telopeptide is a specific protein acting as a biochemical indicator of bone resorption activity by osteoclasts and is considered the most sensitive marker of bone resorption. ${ }^{6-10}$

Prevention and diagnosis of osteoporosis needs to be done early. Gold standard for the diagnosis of osteoporosis is the dual energy X-Ray absorptiometry (DXA) examination. DXA examination has some limitations as it is quite expensive, utilizes ionizing radiation, requires a competent radiologist, and it is not widely available in developing countries like Indonesia. ${ }^{3,11}$

Therefore, several screening instruments to determine the clinical risk of osteoporosis using questionnaire method have been developed. Some of these questionnaires include Osteoporosis Self-Assessment Tool (OST, OSTA), Osteoporosis Risk Assessment Instrument (ORAI), Simple Calculated Osteoporosis Risk Estimation (SCORE) and the Osteoporosis Index of Risk (OSIRIS). All of these instruments considers weight and age variables to identify the risk of osteoporosis. ${ }^{11,12}$ One type of questionnaire to determine the risk of osteoporosis that can be used in Southeast Asian populations is the Osteoporosis Self-Assessment Tool (OSTA). The OSTA questionnaire is quite simple, effective and can be used in everyday clinical practice to assess the risk of osteoporosis in postmenopausal women in Asian countries. ${ }^{13-15}$

The absence of data regarding the correlation between plasma C-telopeptide with osteoporosis risk classification using OSTA in postmenopausal women in Manado encouraged us to carry out a cross-sectional analytic study to evaluate this correlation.

\section{METHODS}

This study was a cross-sectional analytic study conducted in the Department of Obstetrics and Gynecology in Prof. Dr. RD Kandou, Manado. The study was conducted since December 2013, with a total of 31 subjects.

The subjects were postmenopausal women presenting to the Obstetrics and Gynecology outpatient clinic of Prof. Dr. RD. Kandou Hospital, who fulfilled the inclusion and exclusion criteria. Women were included in the study if they were aged between 51 to 65 years and willing to participate in this study voluntarily, as expressed by signing an informed consent form. Exclusion criteria were history of previous bone fracture, amenorrhea due to removal of the uterus or ovaries, history of breast, endometrial or ovarian cancer, having previously been diagnosed with osteoporosis, or having received treatment for osteoporosis (bisphosphonates, vitamin $\mathrm{D}$, calcitonin, fluoride, hormone replacement therapy, calcium supplements). Consecutive sampling method was utilized in the sample collection.

The variables examined in this study were plasma C-telopeptide levels and OSTA score to determine osteoporosis risk classification. C-telopeptide levels were examined in Manado Prodia Laboratory. Blood sampling was carried out after study participants underwent fasting for 12 hours. We collected $0.5 \mathrm{cc}$ of blood and placed into a test tube containing an anticoagulant agent (heparin/EDTA). The blood samples were stabilized at $20-25^{\circ} \mathrm{C}$ for 24 hours or at $4-8^{\circ} \mathrm{C}$ for 8 days.

Osteoporosis risk classification by OSTA score was calculated through the formula $0.2 \mathrm{x}$ weight $(\mathrm{kg})$ - age (years). If OSTA score $<-4$, patient is considered as high risk, OSTA score from -1 to $<-4$ is classified as moderate risk, and OSTA score $>-1$ is considered as low risk for osteoporosis.

\section{RESULTS}

Description of patient characteristics is shown in Table 1. From the 31 samples obtained the youngest age is 52 years old and the oldest is 65 years with a mean age of $58.71 \mp 3.88$ years. The BMI ranged from $15.20 \mathrm{~kg} / \mathrm{m}^{2}$ to $29.10 \mathrm{~kg} / \mathrm{m}^{2}$, with a mean BMI of $21.83 \mp 4.64 \mathrm{~kg} / \mathrm{m}^{2}$. Around half of the samples who participated in this study had low risk OSTA classification, approximately $25 \%$ had moderate risk based on OSTA classification, and almost 23\% had high risk for osteoporosis based on OSTA classification. 
Table 1. Patient Characteristics

\begin{tabular}{lccccc}
\hline \hline \multirow{2}{*}{$\begin{array}{c}\text { Patient } \\
\text { Characteristics }\end{array}$} & n & Mean & SD & \multicolumn{2}{c}{ Range } \\
\cline { 5 - 6 } & & & & Min & Max \\
\hline Age (years) & 31 & 58.71 & 3.88 & 52 & 65 \\
Weight $(\mathrm{kg})$ & 31 & 53.65 & 11.76 & 39 & 75 \\
BMI (kg/m²) & 31 & 21.83 & 4.64 & 15.20 & 29.10 \\
C-telopeptide $(\mathrm{ng} / \mathrm{ml})$ & 31 & 0.52 & 0.25 & 0.19 & 1.19 \\
OSTA & 31 & -1.02 & 2.54 & -4.40 & 2.80 \\
\hline \hline
\end{tabular}

Further normality testing is shown in Table 2, which aims to determine the distribution of the data. Based on the Kolmogorov-Smirnov normality test results, the distribution of C-telopeptide and OSTA is normally distributed ( $\mathrm{p}>0.05)$. Therefore, to determine the relationship between C-telopeptide levels and osteoporosis risk factors based on OSTA classification in postmenopausal women, Pearson correlation analysis was carried out.
The correlation coefficient based on Pearson correlation analysis is -0.768 and $p=0.001$ $(p<0.05)$. This implies the presence of a significant negative correlation between $\mathrm{C}$-telopeptide levels and risk for osteoporosis based on OSTA in postmenopausal women, meaning the higher the $\mathrm{C}$ telopeptide level, the smaller the OSTA score.

To determine the effect of C-telopeptide levels on OSTA scores, simple linear regression analysis was performed. Regression analysis showed that the coefficient of determination $\left(R^{2}\right)$ is 0.589 . This signifies that $\mathrm{C}$-telopeptide variable can explain $58.9 \%$ of OSTA variation and $41.1 \%$ of OSTA variation can be explained by other variables with $\mathrm{p}=0.001$, indicating that $\mathrm{C}$-telopeptide variable can explain or predict OSTA variation significantly. This correlation is illustrated in Figure 1 below.

Table 2. Normality of Data Distribution

\begin{tabular}{lccccc}
\hline \hline \multicolumn{1}{c}{ Patient Characteristics } & n & Mean & SD & $\begin{array}{c}\text { Kolmogorov - } \\
\text { Smirnov Z }\end{array}$ & $\begin{array}{c}\text { Asymp. Sig. } \\
\text { (2-tailed) }\end{array}$ \\
\hline Age (years) & 31 & 58.71 & 3.88 & 0.515 & 0.954 \\
Weight (kg) & 31 & 53.65 & 11.76 & 0.959 & 0.316 \\
BMI (kg/m²) & 31 & 21.83 & 4.64 & 0.928 & 0.355 \\
C-telopeptide (ng/ml) & 31 & 0.52 & 0.25 & 0.764 & 0.603 \\
OSTA & 31 & -1.02 & 2.54 & 0.932 & 0.350 \\
\hline \hline
\end{tabular}

Formula: OSTA $=3.03-7.72$ C-telopeptide

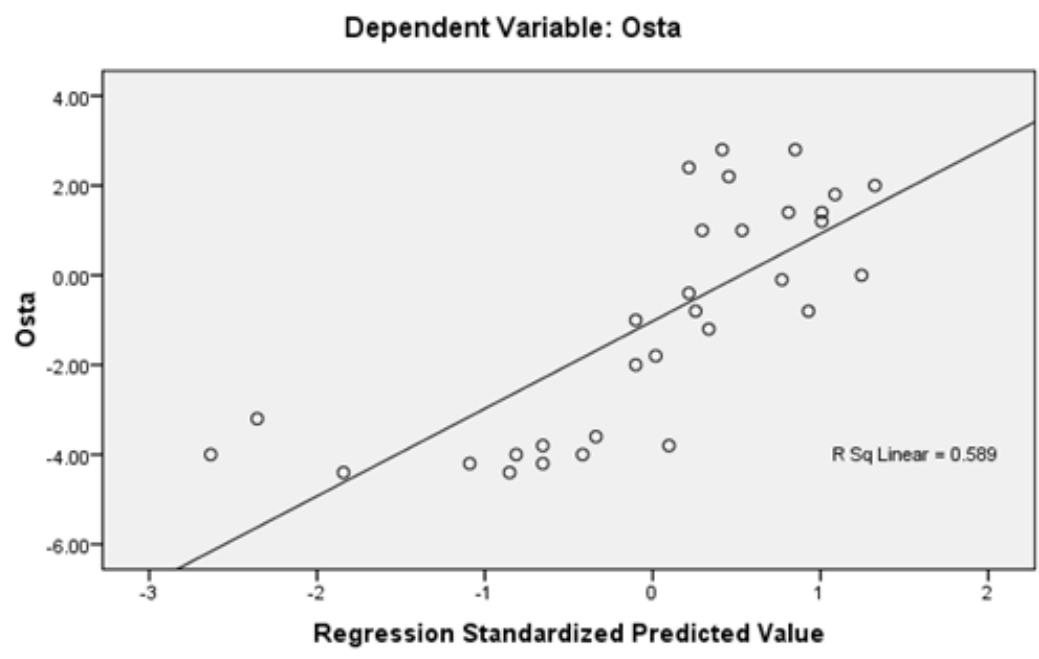

Figure 1. Simple Linear Regression between C-telopeptide and OSTA score. 
Simple linear regression provided a formula of OSTA $=3.03-7.72$ C-telopeptide, indicating that any increase in the levels of C-telopeptide of 1 $\mathrm{ng} / \mathrm{ml}$ will be followed by a decline of OSTA score by 7.72 .

The difference in C-telopeptide levels based on OSTA osteoporosis risk classification of mild, moderate or severe is was analyzed using KruskalWallis test. The results of the analysis is presented in Table 3 below.

Table 3 shows that mean C-telopeptide levels are $0.82 \mp 0.19 \mathrm{ng} / \mathrm{ml}$ in high risk OSTA classification, $0.62 \mp 0.21 \mathrm{ng} / \mathrm{ml}$ in moderate risk OSTA classification, and $0.34 \mp 0.09 \mathrm{ng} / \mathrm{ml}$ in low risk OSTA classification. Kruskal-Wallis analysis showed that $\mathrm{p}=0.001$, meaning that the average C-telopeptide levels in the three categories of OSTA risk classification are significantly different $(\mathrm{p}<0.05)$.

\section{DISCUSSION}

Previous literature have shown that increasing age and weight loss is strongly correlated with a decrease in bone mineral density and an increased risk of fractures. One of the simplest instruments commonly used to identify the risk of osteoporosis in women with the tendency for low BMI is OSTA. This instrument is recommended prior to bone mineral density examination and is quite effective for predicting the risk of osteoporosis in Asian population.

Buttros et al have demonstrated that age at menopause is a risk factor for osteoporosis. ${ }^{16}$ The incidence of osteoporosis also increases in the elderly population. ${ }^{5}$ Therefore, we can conclude the presence of a correlation between osteoporosis with age. $5,14,16,17$

The correlation between BMI and osteoporosis risk in Asian women has been studied by Tao et al in 271 postmenopausal Chinese women, where the mean body weight was $53.4 \mp 9.6 \mathrm{~kg}$ and the mean BMI was $23.0 \mp 3.4 \mathrm{~kg} / \mathrm{m}^{2}$. Their findings demonstrated that low BMI was often found in menopause. ${ }^{14}$ Low BMI is also associated with lower bone mineral density in the general population, especially in the postmenopausal population. Our findings are supported by findings of Nackhbandi et al, who stated that the effect of body weight on bone mineral is greater in specific parts of the body like the weight-bearing bones of the femur and tibia. ${ }^{18}$ Trento et al discovered a negative correlation between C-telopeptide levels and BMI. ${ }^{19}$ Furthermore, Richy et al demonstrated a negative correlation between bone turnover and BMI. ${ }^{20}$ Lateef et al have also established that markers of bone metabolic activity is inversely correlated with BMI. ${ }^{6}$

Studies in the last decade have established the role of leptin in the regulation of bone mineral. Leptin is produced by adipocytes and contributes to the regulation of energy homeostasis through appetite suppression and by increasing the energy usage. Peripheral leptin works in the bone by increasing osteoblast proliferation and bone matrix synthesis, resulting in increased bone mineral. ${ }^{21,22}$

Adipose tissue can alter androgens into estrogen. The more adipose tissue composition in a woman's body, the more estrogen is produced. Overweight women with a high body fat composition will experience less decrease in bone mineral density. 3,18,21,23

Most of our samples were classified as having low risk for osteoporosis based on their OSTA score (more than $50 \%$ of our sample), while approximately a quarter of our sample was classified as having moderate risk and as much as $23 \%$ were considered to have high risk for osteoporosis. This was contradictory to findings of Tao et al in China, where most of the samples were classified as being at high risk for osteoporosis (46.1\%), more than a third of the sample were classified as having mo-

Table 3. Mean C-telopeptide Level Based on OSTA Risk Classification

\begin{tabular}{lccccc}
\hline \hline \multicolumn{1}{c}{$\begin{array}{c}\text { OSTA } \\
\text { Classification }\end{array}$} & $\mathbf{n}$ & $\begin{array}{c}\text { Mean } \\
\text { C-telopeptide }\end{array}$ & SD & $\mathbf{X}^{\mathbf{2}}$ & $\mathbf{p}$ \\
\hline High Risk & 7 & 0.82 & 0.19 & & \\
Moderate Risk & 8 & 0.62 & 0.21 & 22.66 & \\
Low Risk & 16 & 0.34 & 0.09 & \\
\hline \hline
\end{tabular}


derate risk, and only $19.6 \%$ were classified as having low risk for osteoporosis as determined by OSTA classification. ${ }^{14}$

In this study we discovered a significant negative correlation between C-telopetide levels and osteoporosis risk based on OSTA classification in postmenopausal women with a correlation coefficient of -0.768 . This implies that the higher the Ctelopeptide level, the lower the OSTA score.

A cross-sectional study conducted in France showed that bone turnover will increase rapidly after a woman enters menopause age, where there is an increase in osteocalcin and bone alkaline phosphatase levels by $50 \%$, and C-telopeptide levels by $50-150 \% .{ }^{9}$ A study conducted in Manado in 2010 demonstrated that C-telopeptide is an influential variable in the physiological changes occurring in perimenopausal women. ${ }^{24}$ Another study in North Sumatra in 2010 showed that bone turnover is higher in postmenopausal women in comparison to women of reproductive age..$^{25}$ Meanwhile, a study in Pakistan demonstrated the correlation of bone mineral density with osteocalcin and C-telopeptide in postmenopausal women and found a negative correlation between age and bone mineral density. A positive correlation was observed between osteocalcin and C-telopeptide, as well as between $\mathrm{C}$-telopeptide and age.

Salleh et al reported significant elevation in Ctelopeptide and osteocalcin levels in postmenopausal women compared to premenopausal women. ${ }^{26}$ It can be inferred that C- telopeptide is able to determine significant loss of bone structure, and can be used for the assessment of osteoporosis in postmenopausal patients. ${ }^{6,26}$

Chaovisitsaree et al compared the OSTA instrument with bone density examination and found that OSTA had a sensitivity of $36-48 \%$ and specificity of $71-75 \%$ for identifying osteoporosis in postmenopausal women. ${ }^{12}$ A study in China in 2007 demonstrated that a combination of OSTA and phalanx quantitative ultrasound had sensitivity of $80 \%$ and specificity of $84 \%$ in identifying the risk of non-vertebral osteoporotic fracture in postmenopausal women in developing countries. ${ }^{14,15}$ Based on a Singaporean study, OSTA was found to have a sensitivity of $94 \%$ and specificity of $64 \%$ in determining the risk of osteoporosis in postmenopausal women, while a study in Korea showed OSTA to have a sensitivity of $87 \%$ and specificity of $67 \%$. Furthermore, a validation study in China demonstrated that OSTA had a sensitivity of 92\%, and specificity of $54 \%$. A Japanese study further confirms the sensitivity of OSTA, producing a sensitivity of $98 \%$ and specificity $29 \%{ }^{15}$

Based on the results of simple linear regression analysis, the coefficient of determination $\left(\mathrm{R}^{2}\right)$ was found to be 0.589 . This indicates that $\mathrm{C}$-telopeptide is able to explain $58.9 \%$ of OSTA score variation, while $41.1 \%$ of OSTA variation can be explained by other variables.

\section{CONCLUSIONS}

From these results, we can conclude the presence of a negative correlation between plasma Ctelopeptide with osteoporosis risk classification using OSTA in postmenopausal women. Therefore, it is suggested that examination of C-telopeptide levels should be developed in the management of bone metabolism disorders in postmenopausal women. Moreover, OSTA assessment can be applied in the community to screen asymptomatic postmenopausal women with risk for osteoporosis because it is relatively easy and inexpensive, making it suitable for conditions where there is no DXA implement. Further research is needed to determine the sensitivity of both OSTA and C-telopeptide in determining the risk for osteoporosis.

\section{REFERENCES}

1. Baziad A. Osteoporosis dalam: Menopause dan Andropause. Jakarta: Yayasan Bina Pustaka Sarwono Prawirohardjo; 2003: 75-100.

2. Rahman IA. Osteoporosis primer. In: Suherman SK, Tobing SDAL. (Eds.) Osteoporosis. $1^{\text {st }}$ ed. Jakarta: CV Infomedika; 2006: 1-16.

3. Kawiyana IKS. Osteoporosis-patogenesis, diagnosis, dan penanganan terkini. J Peny Dalam 2009; 10(2): 157-69.

4. Turner L, Freemen J. Osteoporosis: it's more than calcium. J Health Promotich 2004; 2(3): 12-29.

5. Sennang AN, Mutmainnah, Pakasi RDN, et al. Analisis kadar osteokalsin serum osteopenia dan osteoporosis. Indones J Clin Pathol Med Lab 2006; 12(2): 49-52.

6. Lateef M, Baig M, Azhar A. Estimation of serum osteocalcin and telopeptide-C in postmenopausal osteoporotic females. Osteoporos Int 2010; 21(5): 751-5.

7. Kawiyana IKS. Crosslink telopeptida C-Terminal (CTx) sebagai petanda aktivitas sel osteoklas pada osteoporosis pascamenopause defisiensi estrogen. J Peny Dalam 2009; 10(2): 79-84.

8. Goudu SVA, Rao VP, Naidu DM, et al. Clinical importance of screen TRAP-5b and urine CTX-1 in the assessment of bone loss in postmenopausal women. Int J Biotechnol Biochemistry 2010; 6(3): 427-34. 
9. Garnero P, Delmas PD. New developments in biochemical markers for osteoporosis. Calcif Tissue Int 1996; 59(Suppl 1): 2-9.

10. Marx RE, Cillo JE Jr, Ulloa JJ. Oral bisphosphonate-induced osteonecrosis: risk factors, prediction of risk using serum CTX testing, prevention, and treatment. J Oral Maxillofac Surg 2007; 65(12): 2397-410.

11. Cook RB, Collins D, Tucker J, et al. Comparison of questionnaire and quantitative ultrasound techniques as screening tools for DXA. Osteoporosis Int 2005; 16(12): 1565-75.

12. Chaovisitsaree S, Namwongprom SA, Morakote N, et al. Comparison of osteoporosis self assessment tool for Asian (OSTA) and standard assessment in Menopause Clinic, Chiang Mai. J Med Assoc Thai 2007; 90(3): 420-5.

13. Chaiyakunapruk N, Laowakul A, Karnchanarat S, et al. Community pharmacy-based implementation and evaluation of an osteoporosis self-assessment tool for Asians. J Am Pharm Assoc 2006; 46(3): 391-6.

14. Tao B, Liu JM, Li XY, et al. An assessment of the use of quantitative ultrasound and the Osteoporosis Self-Assessment Tool for Asians in determining the risk of nonvertebral fracture in postmenopausal Chinese women. J Bone Miner Metab 2008; 26(1): 60-5.

15. Koh LK, Sedrine WB, Torralba TP, et al. Osteoporosis SelfAssessment Tool for Asians (OSTA) Research Group. A simple tool to identify asian women at increased risk of osteoporosis. Osteoporos Int 2001; 12(8): 699-705.

16. Butros Dde A, Nahas-Neto J, Nahas EA, et al. Risk factors for osteoporosis in postmenopausal women from southeast Brazillian. Rev Bras Gynecol Obstet 2011; 33(6): 295-302.

17. Suzuki T. Risk factors for osteoporosis in Asia. J Bone Miner Metab 2001; 19(3): 133-41.
18. Nakchbandi IA, van der Merwe SW. Current understanding of osteoporosis associated with liver disease. Nat Rev Gastroenterol Hepatol 2009; 6(11): 660-70.

19. Trento LK, Pietropolli A, Ticconi C, et al. Role of type I collagen $\mathrm{C}$ telopeptide, bone-specific alkaline phosphatase and osteocalcin in the assessment of bone status in post-menopausal women. J Obstet Gynecol Res 2009; 35(1): 152-9.

20. Richy F, Deceulaer F, Ethgen O, et al. Development and validation of the ORACLE score to predict risk of osteoporosis. Mayo Clin Proc 2004; 79(11): 1402-8.

21. Ormarsdottir S. Osteoporosis in chronic liver disease. Uppsala: Acta Uppsala Universiteit, 2001: 7-47.

22. González-Calvin JL, Mundi JL, Casado-Caballero FJ, et al. Bone mineral density and serum levels of soluble tumor necrosis factors, estradiol and osteoprotegerin in postmenopausal women with cirhosis after viral hepatitis. J Clin Endocrinol Metab 2009; 94(12): 4844-50.

23. Ross PD. Osteoporosis. Frequency, consequences, and risk factors. Arch Internal Med 1996; 156(13): 1399-411.

24. Suparman E, Yusuf I, Tahir AM. Correlation between level of serum estrogen, c-telopeptide, and interleukin- 6 in determining bone density in perimenopausal women. Indones J Obstet Gynecol 2010; 34(2): 84-8.

25. Laily JS. Kadar serum osteocalcin dan c-telopetide darah terhadap turn over tulang pada perempuan pascamenopause di RSUP H. Adam Malik di Medan. Thesis. Universitas Sumatera Utara; 2011.

26. Ardawi MS, Maimani AA, Bahksh TA, et al. Reference intervals of biochemical bone turnover markers for Saudi Arabian women: a cross-sectional study. Bone 2010; 47(4): 804-14. 